\title{
USING ORAI APPLICATION IN TEACHING PRONUNCIATION
}

\author{
Lilis Suryani \\ English Department, Faculty of Language Education, Institut Keguruan dan Ilmu Pendidikan (IKIP) \\ Siliwangi, Indonesia \\ E-mail: lis-suryani@ikipsliwangi.ac.id \\ Trisnendri Syahrizal \\ English Department, Faculty of Language Education, Institut Keguruan dan Ilmu Pendidikan (IKIP) \\ Siliwangi, Indonesia \\ E-mail: trisnendri@ikipsiliwangi.ac.id \\ Ula Nisa El Fauziah \\ English Department, Faculty of Language Education, Institut Keguruan dan Ilmu Pendidikan (IKIP) \\ Siliwangi, Indonesia \\ E-mail: ulanisa@ikipsiliwangi.ac.id
}

\begin{abstract}
APA Citation: Suryani, L., Syahrizal, T., \& Fauziah, U. N. E. (2019). Using ORAI application in teaching pronunciation. Indonesian EFL Journal, 5(2), 93-102. doi: 10.25134/ieflj.v5i2.1835.
\end{abstract}

Received: 21-03-2019

Accepted: 25-05-2019

Published: 01-07-2019

\begin{abstract}
Teaching in 4.0 era cannot be separated with Information and Communication Technology (ICT). There are many applications that can be used in learning and teaching process. ORAI application is chosen to be used as teaching tool in learning pronunciation. The main objective of this research is to discover the pro and cons from students as the main user in using ORAI application in learning pronunciation. This research implemented qualitative as research method and the participants of the research was 35 students of third semester of English students in IKIP Siliwangi. The data were collected by observation and interview. The result of the research showed that most of the participants agree that ORAI brings more benefits in learning pronunciation practice class. Their agreement can be classified into four categories: accessibility, comfortability, technicality, and integrated learning. The students were motivated and they could learn effectively. While, some of the students indicated that they did not want to use this application, they just delivered that this application has weaknesses in their process of practicing English pronunciation. Their cons on the use of ORAI are classified into two categories; topic difficulties and technicalities. Overall, the implementation of ORAI has positive effect for students in pronouncing correctly and they have good feedback to trigger them for practicing a lot. On the other hand, pronouncing English well will make a big contribution to their communication skills.
\end{abstract}

Keywords: accessibility; comfortability; technicality; integrated learning; Information and Communication Technology (ICT); ORAI application; pronunciation.

\section{INTRODUCTION}

The rise of the industrial revolution towards various aspects, the challenges faced also increased. As we know that the Industrial revolution began with Industry 1.0 that together with the invention of paper, changed the way people educate their children from oral to written tradition, whereas Industry 2.0 brought with it mass production and mass education. In the meantime Industry 3.0, triggered by the invention of internet and ICT
(Information and Communication and Technology) development led to online and borderless teacher students' interactions and Industry 4.0 enhances the attainment by such synergetic linking technology as cloud computing, internet of things, with further enhanced artificial intelligence, and virtual and augmented realities (Hocheng, 2018) as cited in (Suherdi, 2018). Thus the involvement of many aspects of industry 4.0 is undeniable. 
Information and Communication Technology (ICT) which has developed recently has become an umbrella for all aspects including the education area. Teaching era in 4.0 cannot be separated with Information and Communication Technology (ICT). ICT has to be involved in learning and teaching process in order to encourage selfregulated learning, and strong and positive character (Suherdi, 2018). It is confirmed by Tinio (2002) as cited in Rahamat (2019), any technologies related to ICT has been announced as potentially powerful enabling tools for educational change and reform. So, ICT can be used as teaching aid for learning and teaching process and it can be trigger for students to learn well.

Because of the enormous role of ICT in education, in the Ministry of National Education Strategic Plan 2005 - 2009 was stated that the strategic role of ICT for the first pillar, namely the expansion and equitable access to education, was prioritized as a medium of distance learning. As for the second pillar, improving quality, relevance and competitiveness, the role of ICT is prioritized for implementation in education or learning processes. Finally, for strengthening governance, accountability and public image, the role of ICT is prioritized for integrated management information systems.

The students of Indonesia are familiar with using the aid of ICT in their daily life, for example personal computer and mobile device or gadget. The activities performed by most of mobile device owners are emailing, text messaging, searching information on the Internet, logging to social networking as well as watching videos or movies (Exact Target as cited in Lee in \& Sulaiman, 2019).

While the students feel happy about ICT in their computer or mobile devices, the teacher can use technology in teaching them in order to make the learning process effectively. ICT gives more benefits in teaching and it has already discussed by some experts. The notion of ICT was posited by Djiwandono (2019), ICT has been an attractive source that provides learning resources, fosters communication and collaboration, and spices up teaching learning activities. It is supported by Rodliyah (2018), ICT can facilitate students' learning and teaching process. In other word, ICT can be one of support systems in teaching in order to make learning process effectively.

There are many kinds of ICT that can be implemented in learning and teaching process. This research implemented ORAI application. ORAI is an application that is developed by Danish Dhamani and it is one of most famous android mobile application. ORAI application helps people to encourage their confident, to sharp their skill to talk in front of people (Bodana, 2017) as cited in (Halimah, Helmie, \& Susilawati, 2018; Halimah, Lustyantie, \& Ibrahim, 2018). ORAI application is easily used, for instance, it has an accurate result analysis. There are three critical factors about analyzes users' speech. First, it looks for the overuse of filler words; second, there is pacing - how fast you're talking; third, there is energy which has to do with vocal variation, also the changes in pitch or volume that make speeches sound interesting. Then, the app presents users with feedback and tips to improve (Macthar, 2017) as cited in (Halimah, Helmie, \& Susilawati, 2018). Thus, ORAI application is suitable to use on teaching learning.

Based on the explanation above, ORAI can help people in learning, especially speaking and it can encourage students' motivation. Brown (2001) as cited in Suryani (2015) defines that speaking as an interactive process of constructing meaning that involves producing, receiving, and processing speech of sounds as main instruments. In other word, teaching speaking involves some steps until students can produce the words. Pronunciation, grammar, and vocabulary are the important elements in speaking. It means that speaking is not an easy skill and it becomes the most stressful for the students.

So, teachers need to seek an appropriate method of teaching to solve the problem 
(Maeng, 2008) as cited in (Suryani \& Argawati, 2018). In fact, it can be challenging for the teacher to select teaching media or method. This is line with Norahmi (2018) as cited in Retnomurti, Hendrawaty, and Tiwiyanti (2019) who said that teachers are required to be competent, professional, up-to-date, and well informed, and they are able to operate any technology based media due to increasing students' ability to get information. Thus, teachers' knowledge and skill to access and use the technology are needed to facilitate the learning and teaching process.

User friendly can be one of the reasons in choosing ORAI application in teaching. The students can download from Play Store on Android system or Apple Store on IOS system. So, it will be easier for students to practice it, they do not only practice in the classroom but also at home.

There are some of the researches that investigated the implementation of ORAI application in teaching speaking, but this research focuses on pronunciation. In short, pronunciation is one of important parts in speaking cycle (Schmitt, 2002). According to Pennington (1994), pronunciation is viewed as a component of linguistics rather than conversational fluency. In addition, Harmer (2007) says that pronunciation teaching does not only make students aware of different sounds and sound feature (and what this mean), but it can also improve their speaking immeasurably.

Pronunciation is one of the subjects that have to be learned by students of English education study program of IKIP Siliwangi, Bandung. There are two kinds of pronunciation subjects, they are pronunciation practice I and pronunciation practice II. This research focuses on pronunciation practice I and it is compulsory subject for third semester. This research would like to know the students' perception about ORAI application in teaching pronunciation practice.

In teaching pronunciation should go beyond just teaching the phonemes. It must also consider other areas such as accent and

\section{https://journal.uniku.ac.id/index.php/IEFLJ/index}

intelligibility and prosodic features of pronunciation (stress, intonation, and rhythm) i.e. the supra-segmental. Additionally, teachers need to identify learners' problematic areas and address the issues accordingly (Shah, Othman, \& Senom, 2017). Thus, the students are able to pronounce correctly, or be able to pronounce the words like native speakers.

Intelligible pronunciation is crucial in communicating and to be understood as without "adequate pronunciation skills, a person's communicative skills maybe severely hampered, and this in turn may give rise to speech that lacks intelligibility, leading to glitches in conversation and to strain on the part of the listener" (Rajadurai, 2006) as cited in (Shah, Othman, \& Senom, 2017). Given the importance of pronunciation skills, one would assume that classroom practices would reflect what is mandated in the curriculum. So, improving the ability to speak English with a good pronunciation is important thing for Indonesian students, because the ability to speak English well will make a big contribution to their communication skills.

\section{METHOD}

This research used qualitative descriptive method. According to Moleong (2002), qualitative research is aimed at understanding the phenomena of what is experienced by the subject of research such as behavior, perception, motivation, holistic actions qualitatively using words and language in natural special contexts by using various scientific methods. In this research, the students' perception as the subject of research was investigated to know their experiences in using ORAI application in learning. This was similar with Creswell (2012) who says that qualitative is used to understand a phenomenon by focusing on the total picture rather than breaking it into variable.

Qualitative research method was interpreted as a research that produces a qualitative data in the form of written or spoken words of the people, and it was to 
describe the participants of the research more complete and comprehensive (Fraenkel \& Wallen, 1993; Moleong, 2002) as cited in (Anshori, 2017). In addition, it described people experience in-depth (Goodyear, et.al, 2014). This was in line with Azwar (1997), in a descriptive method, the researchers analyze and present the fact systematically, and therefore it could be understood and concluded easily.

The main objective of this research was to discover the pro and cons from students as the main user in using ORAI application. This technology based application was mainly used to trigger students in producing proper English sounds and also give wider opportunity for students to practice their pronunciation inside and outside classroom. With this specific objectives, the teacher as facilitator and observer combined a pronunciation practice class with ORAI application. After the use of it, the researchers found the students' perception, in order to find whether most of the students were in pro or cons in the use of this application and the reason behind those decisions.

The subject of this research was third semester students of private Education Institute in Cimahi majoring English Education. They took Pronunciation Practice class as one of their required subject in the third semester. There were 35 students with same English ability namely IntermediateEnglish level and all of the participants were also native speaker of Indonesian.

Classroom observation was used to invent a natural situation on using ORAI application during the process of teaching and learning in pronunciation practice class. It was conducted into five meetings. The result of observation was used to answer the research question of this research. The interview then was conducted to validate the finding during the observation process. During the observation, the research used log book to create more holistic finding. During the interview the research used question that adopted from several resources that related to the students' perception in using assisted based learning. In short, this research used two simultaneous steps to collect the data.

Data were analyzed and it was an interpretative process. Researchers reflect on their personal viewpoints and how they shape their interpretations of the data (Clark \& Creswell, 2015). All gained data from observation's log book then transcribed into excel order to manage the students' perception in more readable result. All the data then synchronized with the result of the interview. All the answer of the participants then also transcribed into excel and matched with the previous result obtained from the observation process. The result of this study cannot be generalized to other social situation (Sugiyono, 2013). In other word, the findings of this research could not be referred as the result as general in implementing ORAI in teaching pronunciation.

\section{RESULTS AND DISCUSSION}

This research was conducted into five meetings. Observation was done when learning and teaching process while the lecturer was implementing ORAI application in teaching pronunciation. Here was the detail information of the implementation of ORAI in teaching.

The first meeting was conducted in September $17^{\text {th }}, 2018$ and the material was producing vocal (mono short and long vowel sound). At the beginning of the class, ORAI application was introduced by the lecturer as the application that was used in learning. The students were not familiar with this application, so the lecturer needed more time to explain how to use this application. Although, ORAI application was used at the first time, the students were really excited to use it. They were motivated to use it. It could be seen from their enthusiasm to use and discuss it with their friends in the classroom.

Then, the second meeting was done in September $24^{\text {th }}, 2018$ and the students used ORAI for the second time in the classroom. This meeting, the students were familiar how to use it and the material that was explained by the students was producing trip thongs 
sound. The third meeting material was producing consonant sounds and it was conducted in October $1^{\text {st }}, 2018$. Next meeting was conducted in October $8^{\text {th }}, 2018$ and the material was producing consonant and sound. The last meeting was conducted in October $15^{\text {th }}, 2018$ and the material was suprasegmental element (intonation, phase, pause, stress, and prominence).

After the last meeting, the interview was done and asked nine students about the implementation of ORAI application, strengths and weakness of this application. The interview of students was recorded and then transcribed. The result of students' interview was categorized based on pros and cons of the implementation of ORAI in teaching pronunciation.

Over the observations, the writers discovered new cycle of learning and practicing students' pronunciation, this cycle began with recording, and receive, revising, and reproduce (4Rs cycle). Reproducing process was the ending of the cycle but its return to the first process of the cycle. The end of the process occured when the students could produce most standard English sounds. The cycle of this process can be seen the figure 1 .

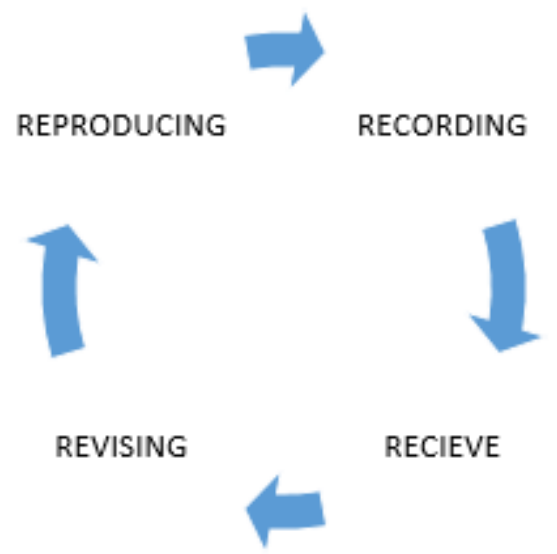

Figure 1. Learning cycle using ORAI application

The first stage was recording, in this stage students recorded their word, utterance and speech. ORAI application provided a text to read, a topic to expand, and question to answer. By this, the students do not need to confuse themselves to find a topic to talk

\section{https://journal.uniku.ac.id/index.php/IEFLJ/index}

about yet the students still need to manage their idea related to the provided materials from ORAI. Students also had more autonomous situation, they could record whenever their ready and also could ask teacher for the standard pronunciation before they record their sounds.

The second stage was receiving, in this stage the students listen to their recorded sound and do self-assessment. Besides, the recorded sounds, ORAI also provides a transcript of the students' talk. It also provided the sore that projected in the percentage of achievements. This percentage indicated how suitable the students talk with the standard talk. The higher the percentage was better student's speech means. During this process $O R A I$ also provided visual report projected by graph. This graph helped the students and the teacher to see the progress made by the students.

The third stage was revising, ORAI provided several option in the process of revising. First, if the speech of students was out of the topic or not read the exact similar text, ORAI would automatically ask students to revise it and reproduce it. Second, if the number of the percentage was low, ORAI would give the options for students to rerecord the sound based on comments that given by ORAI or leave the score. Third, even if the percentage of the students' talk is high, ORAI still gave an option to the students whether they wished to reproduce their talk and make a better score or stay with the score. In this revising process teacher also gave comment how to create a better sound. ORAI did not give the detail information related to the students' weaknesses, but it gave a general example of standard pronunciation. ORAI did not give each word miss pronunciation. By these situations, teacher provided more detail correction toward students' pronunciation errors.

The next stage was reproducing. After finished with revising the talk, the students reproduced their talk by re-recording it through ORAI. Students had their own freedom to reproduce their speech to get their 


\section{Lilis Suryani, Trisnendri Syahrizal, \& Ula Nisa El Fauziah \\ Using ORAI application in teaching pronunciation}

whished score and after that collect it to the teacher. This condition initiated better confidence of the students. In the observed class, students were laughing and chatting with their friends about the audio they record after doing revision, this process really helpful to build students confidence and ability to produce a standard sound of English.

Other result from the observation was the students look very happy during their process of learning. Students looked very enjoy recording their own sounds then listening it, they looked enjoy because they had their own freedom to talk without direct assessment given by the teacher that may rise the nerve of the students. Moreover, students also had an opportunity to give a peer feedback to their friend, this peer feedback also gave benefit to the students' comfort, by peer feedback student be more relax and away from personal nerve that come by teacher assessment.

From 35 or $86 \%$ participants or 30 participants agree that ORAI really helps them in improving their pronunciation skill then help them to be more confident in doing English speaking with proper sounds. While in the other hand, 5 students or $14 \%$ participants think that it was very difficult to do pronunciation practice with ORAI. Figure 2 showed you the pros and cons toward the use of $O R A I$ in pronunciation practice class.

\section{Pros on ORAI}

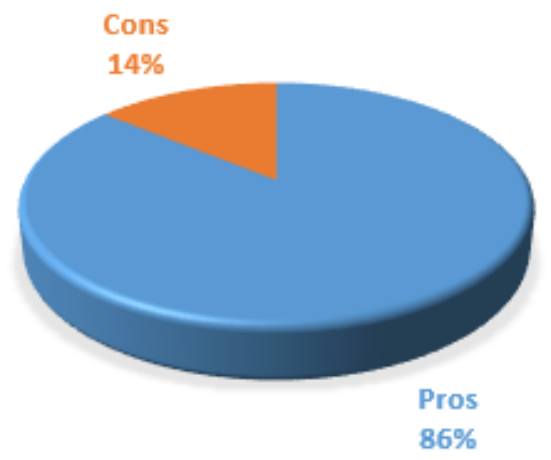

Figure 2. Pro and cons on ORAI

COBUILD Advanced English Dictionary (2018) defines about 'pros and cons' of something are its advantages and disadvantages, which you consider carefully so that you can make a sensible decision. From the figure 2 can be seen that most of the participants agree that ORAI bring more benefits to the teaching and learning process in pronunciation practice class. Their agreement could be classified into 4 categories: accessibility, comfortability, technicality, and integrated learning. These categories appeared from the various reasons that found during the observation and interview session. This is in line with Chapelle (2003) as cited in Rahamat (2019), the technology-based learning activities would offer more advantages and opportunities for natural learning. So, the students' achievement had already increased and it gave a good impact for the students' ability in learning. Here was the detail explanation about the students' perception toward the use of ORAI application in teaching pronunciation based on observation and interview that were analysed based on four categories.

\section{Accessibility}

On problems, many students had limited time to practice their pronunciation due to several reasons, such as limited time in one term of learning that mostly spent 100 minutes per session and huge number of students in class. By the use of ORAI, students had more access to their individual practice related to the speaking specifically on their pronunciation development.

During observation session every student had an equal opportunity to practice themselves in producing their speech and practicing their English pronunciation. Students with their own mobile device conducted the 4Rs cycle as much as they wanted without being afraid of taking turn with their friends which create harder access. As well as in the interview session most of the students believed that by using ORAI, they should not wait for their time to practice they could practice it at any time they ready to start recording their speech.

Moreover, by using ORAI they had more opportunity to get more feedbacks. Usually feedbacks only given by the teacher after students did practice in the front of the 
teacher. By the use of ORAI feedback also could be given by their friend. By using ORAI, students could share the topic of the talk, the question or the text that they read in ORAI. This kind of feedback helped to build their confident and braveness to talk in public and to practice their pronunciation, even students could get over it. This result also supported by the interview result, students feel very comfortable with the feedback that given not only from the teacher but also from their friend and ORAI.

Additionally, students did not need to be afraid of losing their time to practice their pronunciation, because they could do practice in class room and outside the classroom, this situation gave wider and longer chance for the students to practice their pronunciation. Students did not need to practice in classroom they could practice it in their home, garden, and others. They also could practice their pronunciation at any time and keep getting feedback from ORAI. Therefore, they were still able to improve their pronunciation.

\section{Comfortability}

Based on the observation, students seemed to be more comfortable practicing their pronunciation. Formerly, students practiced their pronunciation in front of the class and teacher gives direct correction, this process made students more nervous and gave less comfort to the students. ORAI did different way. ORAI was able to reduce students' nerves in practicing their pronunciation. Students became more comfortable to practice their speaking without being afraid or making mistake. As supported by the result of the interview, most of the participants believed that they no longer afraid to talk and practice their speaking and pronunciation. Beside, ORAI also gave individual feedback to the user in this case the students. Another case that could be found in the use of ORAI was that if the students felt shy or uncomfortable with their result they could simply save it for themselves and nobody would notice it so that students felt lees frightening, more

\section{https://journal.uniku.ac.id/index.php/IEFLJ/index}

comfortable, and more confidence in practicing their pronunciations.

Moreover, one of the problems that students faced in practicing their speaking and pronunciation was they being shy. Some students felt shy because they did not pronounce the word as good as other friends did. This application helped students in solving this problem. They got more confidence to practice their pronunciation because they had individual access without being compared with other students.

By this condition, students felt more comfortable in practicing pronunciation using ORAI. This application is an excellent app to be used as a supporting media for speaking class (Halimah, Helmie, \& Susilawati, 2018; Halimah, Lustyantie, \& Ibrahim, 2018). It provoked the students to learn actively and happily in the classroom. Students got feedback and revised it. So, they could be independent learners and the teacher as the facilitator in learning and teaching process.

\section{Technicality}

ORAI was an application that can be used by anyone who wished to improve they language skill especially their listening and speaking. The sub-element of speaking like pronunciation was one thing that was focused. In the beginning, all of the students were not familiar with this application. Therefore, the first thing that the researchers did is introducing ORAI to all students. Students did not feel too hard to access it because ORAI could be found in the Apple store of IPhone user, Google Play for the android user and web for students who wish to use it in PC or laptop. By these three possible ways, most participates agree that ORAI was very accessible for anyone and it gave an ease in operating it. Moreover, ORAI was a free application. By asking students to download it, we did not give them a burden to spend some amount of money.

Another benefit of the use of ORAI based on the interview was that ORAI did not require high ability level of technology. In other words, ORAI was very user friendly with easy transition and instruction. Based on 


\section{Lilis Suryani, Trisnendri Syahrizal, \& Ula Nisa El Fauziah \\ Using ORAI application in teaching pronunciation}

this explanation that $O R A I$ gave an ease not only for the students but also for the teacher, both teacher and students could have an easy access to ORAI and used it during the instructional process.

\section{Integrated learning}

As we know that speaking and listening were two skills that highly connected. Listening was one of the receptive skills that could help to improve the speaking skill as a productive skill. By listening English sounds, students got various references to pronounce an English words and giving English speech. By using $O R A I$, students can also practice their listening. In the second level of ORAI students would hear two different sounds with different characteristics of sound such as different accent, speed, pauses and others. By listening to this recording, students had a reference to imitate the sound.

As the result, students could pronounce the English words properly. Besides, these two skills, reading was also a skill that could be improved by using ORAI. As mentioned earlier, ORAI provided a text to read by the students, although ORAI did not provide question to measure the reading comprehension of the students, it still helped the students to practice their reading skill. On the interview, students felt happy because they could practice not only their speaking but also their listening and reading.

\section{Cons on ORAI}

As previously stated, five of thirty-five participants gave their negative perception toward the uses of ORAI application. They disbarment did not indicate that they did want to use this application, they just delivered that they had problems in implementing ORAI. Their cons on the use of ORAI were classified into two categories; topic difficulties and technicalities. Here is the detail explanation.

\section{Topic difficulties}

Some students thought that limited topic, limited question, and provided text to be read and gave them less freedom to choose. As result, students felt less comfortable to talk. As example they should read a text that they did not understand what did the text means and it made them feeling hard to read it and of course would make them to record it over and over again which made them uncomfortable.

Moreover, they also some time found a difficult vocabulary to pronounce, and again it made them have to record their sound more than one time. Students also thought that the topic provided in ORAI also not suitable with the context of the study, sometimes the topic went too wide. On interview, students felt more comfortable to talk and practice their pronunciation with the topic that they chose by them and also answered the question that the teacher gave compared to the question ant given by ORAI. They argued that the question from the teacher was more contextual.

Moreover, recording the students' speaking more than one time on the other hand could downgrade their confident in producing their speaking. It happened because not everybody should do the task several times some often could do it just in one time, and the former situation did not change at all. Some students would still good and some other will not. This condition was getting worse by the situation that the students who did it only one times and it gave negative effect toward the learning process.

These difficult topics gave a narrow opportunity to the students who actually having average ability in English. Since, that the topic was too difficult, they could not pronounce the words as they wish. On the other hand, teacher also could not give a major help to this problem since the idea of the students could not simply added by comment from the teacher.

Besides a difficult topic, some questions that were provided by $O R A I$ was also quiet difficult for some students, for example in the level 1 of ORAI asked about what project that students had been doing what their goal, what have achieved and what had not. The students who felt disagree of the use of ORAI thought that this kind of question was too hard for them. They felt better to practice their pronunciation by only answering their 
common question because the word that be pronounced would be very applicable to their daily live.

During the interview the students said that indeed ORAI gave a lot of benefit the learning process, but they prefered do all the pronunciation activity with classroom practice that provide by the teacher instead by using ORAI. They believed that teacher would more aware about the students' psychology so than when the students got wrong, the teacher would not only give correction but also encouragement for the students. From this interview response we could say that this technology really helped the students yet could replace the existence of the teacher and the major function of the teacher in the classroom.

\section{Technicality}

As the opposite opinion, some students discovered some difficulty in accessing ORAI. As internet based application the speed of the interned become one of the most fundamental elements in using ORAI. In some cases, students have limited access to the internet would automatically have limited access to the use of ORAI. Other cases that occurred are, after they recorded it the connection went wrong and they have to record it again. Moreover, they also thought that outside classroom activity also gave more burdens to the students. They believed that $O R A I$ could not truly use anywhere due to connectivity problems.

Others technicality issue that faced by the students was guarding system that have by ORAI. Even though ORAI did not require payment on the usage, this application regularly asked the students or the user to upgrade the application, this process of upgrading became the obstacle for the students. The case that found during the observation was that 3 students had a different progress with other students because they have to wait their application to be upgraded. ORAI application did not give an option to postpone the upgrade, if they asked to be upgraded the use should upgrade unless that could not use it. This issue which strengthen by the statement from the

\section{https://journal.uniku.ac.id/index.php/IEFLJ/index}

interview. Since they had lower progress their losing their spirit to continue their learning activity and at the end they could not practice their pronunciation as much as they did.

Other technicality problems that faced by the students was in the sense of distraction. During the process of learning teacher could not give a maximum control toward the use of students' mobile devices. This condition that used by some of the students to use their mobile device for different purposes such as playing other games, opening their social media, and others. This condition would clearly affect the affectivity of instructional process.

\section{CONCLUSION}

Based on the findings and discussions, there are two kinds of the answer, the first is pros and the second is cons the implementation of $O R A I$ in learning pronunciation based on the students perception. The result of the research showed that most of the participants agree that ORAI brings more benefits to the teaching and learning process in pronunciation practice class. From 35 or $86 \%$ participants or 30 participants agree that ORAI really helps them in improving their pronunciation skill and help them to be more confident in doing English speaking with proper sounds. On the other hand, 5 or $14 \%$ participants think that it is very difficult to do pronunciation practice with ORAI.

Their agreement can be classified into 4 categories, they are accessibility, comfortability, technicality, and integrated learning. While, some of the students did not indicate that they did not want to use this application, they just delivered that this application has weaknesses. Their cons on the use of ORAI are classified into two categories; topic difficulties and technicalities. On the other hand, the teacher should think a lot especially about the topic for the student. The topic has to be suitable with the students' ability and level. Besides, the internet connection can be challenging for the implementation of this application. 


\section{Lilis Suryani, Trisnendri Syahrizal, \& Ula Nisa El Fauziah \\ Using ORAI application in teaching pronunciation}

So, a good connection can help the students learn effectively.

\section{REFERENCES}

Anshori, D. S. (2017). Framing of journalism discourse to improve discourse competence of senior high school students. English Review: Journal of English Education, 6(1), 137-146. doi: 10.25134/erjee.v6i1.780.

Azwar, S. (1998). Metode penelitian. Yogyakarta: Pustaka Pelajar.

Clark, V. L. P., \& Creswell, J. W. (2015) Understanding research: A consumer's guide ( $2^{\text {nd }}$ ed.). NJ: Pearson Education, Inc.

Creswell, J. W. (2012). Educational research: Planning, conducting and evaluating quantitative and qualitative research. New York: Pearson.

Djiwandono, P. I. (2019). How language teachers perceive information and communication technology. Indonesian Journal of Applied Linguistics, $\quad 8, \quad 608-616 . \quad$ doi: 10.17509/ijal.v8i3.15260.

Fraenkel, J. R., \& Wallen, N. E. (2007). How to design and evaluate research in education $\left(6^{\text {th }}\right.$ ed.). New York: McGraw-Hill International Edition.

Goodyear, L., Jewiss, J., Usinger,J., \& Barela, E. (2014). Qualitative inquiry in evaluation. San Fransisco: Jossey_Bass.

Harmer, J. (2007). The practice of English language teaching ( $4^{\text {th }}$ ed.). Cambridge: Pearson Education Limited.

Halimah, H., Helmie, J., \& Susilawati, N. (2018). Orai application to promote autonomous learning to English learner at senior high school. IJET, 7(2).

Halimah, H., Lustyantie, N., \& Ibrahim, A. G. (2018). Students' perception on the implementation of ORAI application in CLL method in teaching speaking. JEELS, 5(2).

Lee, T. H., \& Sulaiman, R. (2019). Preliminary analysis of wireless collaborative network on mobile devices. Journal of Information and Communication Technology, 18(3), 327- 343.
Pennington, M. (1994). Recent research in L2 phonology: Implications for practice. In J. Morley (Eds.), Pronunciation pedagogy and theory: New views, new directions (pp. 92-108). TESOL Publications ISBN: 9780939791552.

Rahamat, R. (2019). Designing mobile learning: Empirical journey to reality in Malaysian secondary school context. EduLite Journal of English Education, Literature, and Culture, 4(1), 13-24.

Retnomurti, A. B., Hendrawaty, N., \& Tiwiyanti, L. (2019). Development of Android-based Protadroid application in pronunciation practice learning for undergraduate students. English Review: Journal of English Education, 7(2), 6776. doi: 10.25134/erjee.v7i2.1721.

Rodliyah, R. S. (2018). Vocational school EFL teachers' practices of integrating ICT into English lessons: Teachers' voices. Indonesian Journal of Applied Linguistics, 8, 418-428. doi: 10.17509/ijal.v8i2.13309.

Shah, S. S. A., Othman, J., \& Senom, F. (2017). The pronunciation component in ESL lessons: Teachers' beliefs and practices. Indonesian Journal of Applied Linguistics, 6(2), 193-203.

Sugiyono. (2013). Metode penelitian pendidikan pendekatan kuantitatif, kualitatif, dan $R \& D$. Bandung: Alfabeta.

Schmitt, N. (2002). An introduction to applied linguistics. London: Oxford University Press.

Suherdi, D. (2019). Teaching English in the industry 4.0 and disruption era: Early lessons from the implementation of SMELT I 4.0 DE in a senior high lab school class. Indonesian Journal of Applied Linguistics, 9, 67-75. doi: 10.17509/ijal.v9i1.16418.

Suryani, L. (2015). The effectiveness of role play in teaching speaking. ELTIN JOURNAL, Journal of English Language Teaching in Indonesia, 3(2).

Suryani, L., \& Argawati, O. A. (2019). Risk-taking and students' speaking ability: Do they correlate? ELTIN JOURNAL: Journal of English Language Teaching in Indonesia, 6(1). 